\title{
EXPERIMENT AND ANALYSIS OF CAR AlternAtor FOR WIND TURBINE APPLICATION
}

\author{
Pudji Irasari \\ Research Centre for Electrical Power and Mechatronics - Indonesian Institutes of Sciences \\ Komp. LIPI Bandung, Jl Sangkuriang, Gd 20, Lt 2, Bandung, \\ West Java 40135, Indonesia \\ pudji.irasari@lipi.go.id
}

Received: February $1^{\text {st }}$, 2011; Revised: February $8^{\text {th }}$, 2011; Accepted: April $8^{\text {th }}$, 2011; Published online: July $7^{\text {th }}, 2011$

\begin{abstract}
Abstrak
Makalah ini membahas eksperimen dan analisis untuk mengetahui kelayakan alternator mobil sebagai generator turbin angin. Eksperimen dilakukan dua kali. Eksperimen pertama adalah karakterisasi alternator untuk menentukan rasio transmisi mekanik. Dalam eksperimen ini alternator diputar oleh mesin bubut dan daya keluarannya digunakan untuk mengisi baterai. Dalam eksperimen kedua, alternator diintegrasikan dengan baling-baling dan mengujinya sebagai satu kesatuan sistem. Simulasi kecepatan angin dilakukan menggunakan terowongan angin. Dalam kedua eksperimen tersebut pembangkitan listrik alternator dilakukan dengan metoda fixed excitation current. Korelasi antara karakteristik alternator dengan tip speed ratio menghasilkan rasio transmisi mekanik sebesar 1 : 3. Hasil pengujian menunjukkan bahwa efisiensi alternator sekitar 50\% dan cut-in wind speed (setelah perhitungan koreksi) adalah $6.35 \mathrm{~m} / \mathrm{s}$.
\end{abstract}

Kata kunci: alternator, mobil, fixed excitation current, turbin angin.

\begin{abstract}
This paper discusses experiment and analysis to find out the feasibility of a car alternator to be used as a generator for wind turbine. The experiment was conducted twice. The first experiment was to characterize the alternator to determine the mechanical transmission ratio. In this experiment the alternator was driven by a lathe machine and its output power was supplied to charge a battery. In the second experiment the alternator was integrated with the turbine blades and they were tested as a unit system. In both experiments, the electric generation of alternator was executed with fixed excitation current method. The correlation between the alternator characteristic and the tip speed ratio gives the mechanical transmission ratio of $1: 3$. The experiment results show that the efficiency of alternator is around 50\% and cut-in wind speed (after correction) is $6.35 \mathrm{~m} / \mathrm{s}$ indicating that alternator is not feasible for wind turbine system application.
\end{abstract}

Key words: alternator, car, fixed excitation current, wind turbine.

\section{INTRODUCTION}

The electrification ratio of Indonesia is $66 \%$ [1]. This coerces part of the society to fulfill their electricity self-reliance by utilizing surrounding potential energy sources. One of the attractive energy sources is wind energy since almost all of the components of small wind turbine can be easily made by small local workshops.

Among the components that are demanded to be found in local market yet bear high cost for still being imported is low speed generator. This condition has driven people to make use of any available and cheap generator types. One of them is car alternator.

Discussions on the feasibility of car alternator for wind energy system are still going on. Some conducted researches utilizing car alternator as generator in wind turbine system are [2][3][4]. Research [2] used a Windpro2004 wind turbine that could generate $163 \mathrm{~W}$ electric power with wind speed around $9 \mathrm{~m} / \mathrm{s}$ and the selected gear ratio was 1:4. In the generator section, an excitation supply was provided as the generator exceeds a pre-determined speed (rpm) preserving the battery from draining unnecessarily. The field controller circuit automates this function. When the battery is fully charged and the rotor exceeds the safe rpm, a braking system is activated automatically by using a resistive dump load. Under the experimental conditions the wind turbine could generate $18.75 \mathrm{kWh}$ per month at $4.8 \mathrm{~m} / \mathrm{s}$ of average wind speed.

In research [3] the car alternator is mechanically coupled to the shaft of a squirrel cage induction motor, which is controlled through an AC drive that simulates the variable speed wind. The old rectifier diode array of the alternator was replaced with the new one that not 


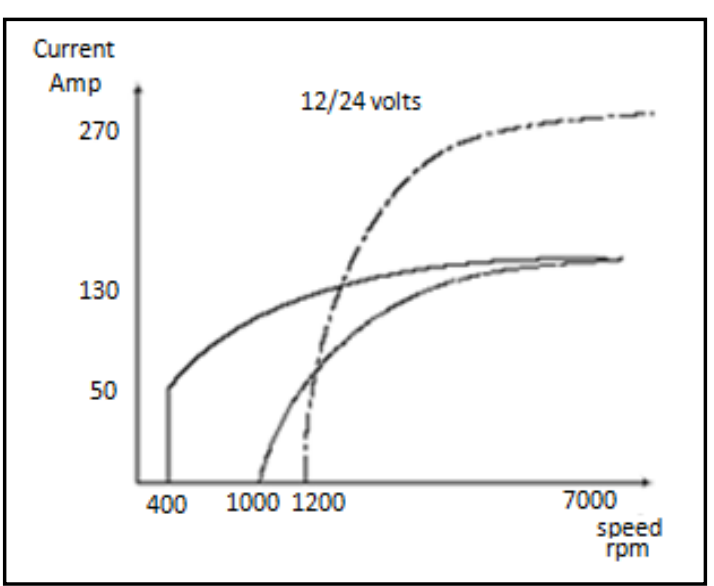

Figure 1. Characteristic of current - speed measured from three car alternators.

only providing a basic DC output but also incorporating both a field and an output voltage regulators in the same case. From the tests performed, $87 \%$ of overall system efficiency was obtained. This achievement is very good but there is no information on how much power consumed by the controller.

The rotor type used in [4] was of double step savonious rotors. In order to obtain power at low speed, the conventional car alternator winding was modified (rewound). The built prediction data for the prototype on mechanical power, rotational speed, nominal wind speed, and efficiency are $81 \mathrm{~W}, 386 \mathrm{rpm}, 10 \mathrm{~m} / \mathrm{s}$ and 29\%, respectively.

This paper will discuss the feasibility of car alternator for wind turbine application with fixed excitation current.

\section{THEORY}

\section{A. Car Alternator}

It is already known that a car alternator usually starts producing electric power at a high speed which is around $1000 \mathrm{rpm} \mathrm{[2][4][5].}$ However, an experimental work carried out in [3] shows the possibility for generating energy at low rotational speed, as illustrated in Fig. 1.

In principle, alternators work similarly to generator, which is converting mechanical energy into electrical energy. In Indonesia, the term of "alternator" is frequently related to the automotive application while "generator" is for electric power plant.

Knowing the alternator characteristic is a very important point, particularly to match wind turbine and alternator speed in order to obtain the smallest gearbox ratio. Fig. 1 has a drawback since it does not present complete information particularly on the magnitude of the excitation current. In an automotive system, excitation current is drawn automatically by a voltage regulator. The lower the battery level, the higher the excitation current drawn by the regulator which leads to higher reverse torque.

The working principle of car alternator in more detail can be explained with the help of Fig. 2 . When the key is turned on, current from the ignition switch flows to the rotor through voltage regulator. Since the rotor is spinning, a pair of brushes that makes constant contact with two slip rings on the rotor shaft is required. This causes the rotor to become magnetized and the alternator is producing alternating current in the stator.

Afterward, the alternating current has to be converted to direct current by using a series of 6 diodes that are mounted in a rectifier assembly. The direct current leaves the rectifier through the B terminal. Connected to the B terminal of the alternator is a fairly heavy wire that runs straight to the battery.

Current generated by the ignition switch and flows in the field coil, is usually called as "field current" or "excitation current". The voltage

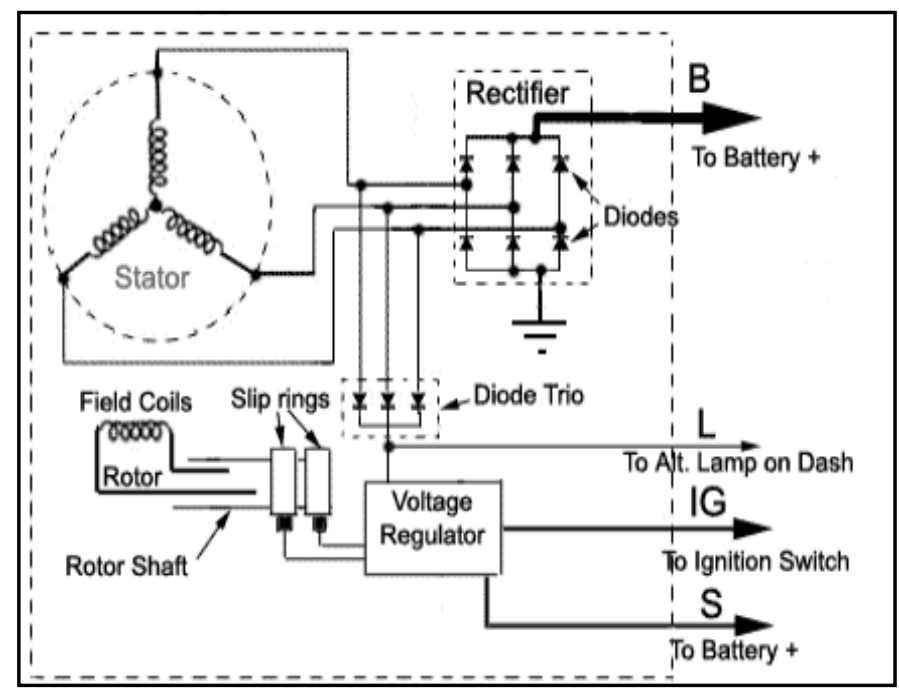

Figure 2. Typical alternator circuit. 
regulator monitors the voltage coming out of the alternator and, when it reaches a threshold of about 14.5 volts, the regulator reduces the excitation current in the rotor to weaken the magnetic field. When the voltage drops below this threshold, the current flows to the rotor is increased.

There is another circuit in the alternator to control the charging system warning lamp that is on the dash. Part of that circuit is another set of diodes mounted inside the alternator called the diode trio. The diode trio takes current coming from the three stator windings and passes a small amount through three diodes so that only the positive voltage comes through. After the diodes, the wires are joined into one wire and sent out of the alternator at the $\mathrm{L}$ connection. It then goes to one side of the dash warning lamp that is used to indicate when there is a problem with the charging system. The other side of the lamp is connected to the run side of the ignition switch. If both sides of the warning lamp have equal positive voltage, the lamp will not light. Remove voltage from one side and the lights on to inform there is a problem.

For wind power application, the rising of excitation current will be sensed as a shocking break that could stop the blades from rotation and, when it frequently happens, damage the mechanical components such as bearing and shaft.

Therefore, in order to have smooth operation, it is better to set the excitation current at a certain value. An experiment is, therefore, required to find out the most appropriate excitation current from the torque and rotation point of views.

\section{B. Tip speed ratio}

In this research, tip speed ratio is one of the main parameters to determine gearbox ratio. The unavailability data of the tip speed ratio of the wind turbine used is approached using the graph showing a relationship between power coefficient $c_{\mathrm{p}}$ and tip speed ratio $\lambda$, as illustrated in Fig. 3. The wind turbine used is of three-blade types, so according to Fig. 3, the corresponding tip speed ratio is in the range of $5-11$.

\section{EXPERIMENT}

\section{A. Alternator Performance Test}

Ideally, a generator or a car alternator laboratory performance test is conducted by employing a set of AC or DC motor with speed controller as performed in [3][8][9].

However, since such experiment set-up was not available in the laboratory, a lathe machine was utilized instead. This machine has speed setting of 220, 300, 400, 540, 720, 980, 1300 and $1800 \mathrm{rpm}$ which means that the experiment speed variations are very limited. The experiment circuit is illustrated in Fig. 4. The driver $M$ is a lathe machine coupled directly with the alternator G. The alternator $G$ has no technical specification except it is from MagnetiMarelli brand and for use in car Chrysler/Sinca. The DC power supply is functioned as excitation current injector to the alternator $\mathrm{G}$ so it can generate electricity.

The higher the excitation current, the higher the output power will be. All of the output power is flowed to the battery. At the beginning of the experiment the excitation current should be set at

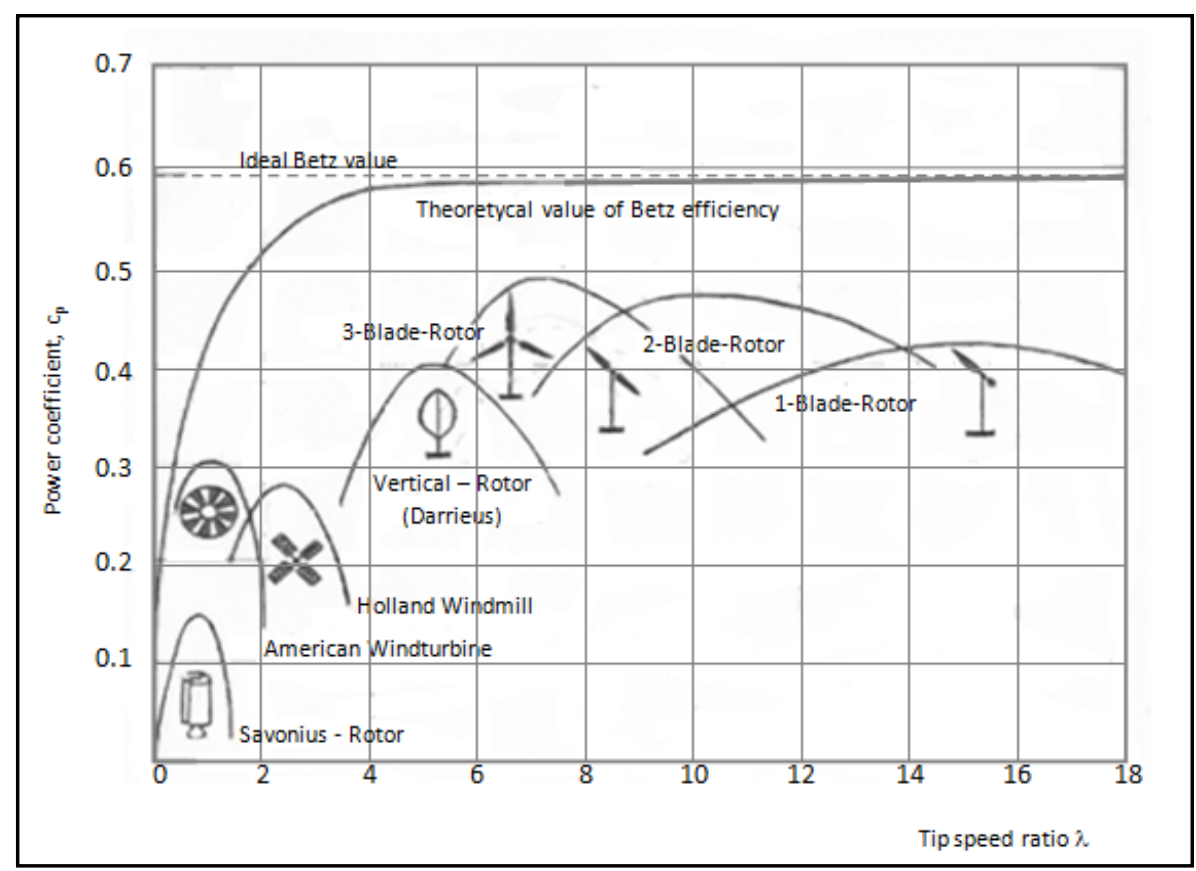

Figure3. The graph of power coefficient $c_{\mathrm{p}}$ vs. tip speed ratio $\lambda$. 
a certain value and the battery should be fully charged $( \pm 13 \mathrm{~V})$. As the experiment started, the battery is discharged by turning on the load (variable lamps), and at the same time the battery is charged by the alternator. The load is increased randomly until the battery voltage is down to $12 \mathrm{~V}$. This procedure is repeated with different excitation current and speed setting. Since generally car alternator starts generating electricity at around $1000 \mathrm{rpm}$, this speed is set to become the minimum speed for this experiment. The power generation method of alternator under constant field excitation has also been carried out within [8], giving better efficiency than internal regulator

The other parameter measurement to obtain is the torque. The experiment set-up for torque measurement is shown in Fig. 5, based on the method described in [10]. The shaft of alternator and lathe machine are coupled so that the alternator's body could hang freely (Fig. 5(a)). The imbalanced position of alternator due to fixation gives some force at no load condition (Fig. 5(b)) $\mathrm{F}_{0}=0.6 \mathrm{~N}$. Therefore, the measured force, $F_{m}$, should be subtracted by this value to obtain the net force, F. The length of the arm (l) is $0.26 \mathrm{~m}$. The recording of the torque is done along with the other electrical parameters, which are current and voltage at every load set.

\section{B. Alternator Performance Test}

There are a lot of data obtained from the alternator performance test but only one experiment setting, which is one speed with two excitation current, presented here to give a figure of mechanical power and efficiency calculations. Furthermore, the other data can be similarly calculated. The experiment result is shown in Table 1.

Torque is calculated using equation [11]:

$$
T=l \cdot F
$$

where $\mathrm{l}=$ the length of cantilever, and $\mathrm{F}=$ the net force obtained from

$$
F=F_{m}-F_{0}
$$

For simplicity, only the measured force presented in Table 1, which is the net force directly involved in the calculation of efficiency.

Mechanical power can be found as [12]

$$
P_{\text {mech. }}=T \cdot \omega_{m}=T \cdot \frac{2 \pi n_{\text {alt }}}{60}
$$

where $n_{\text {alt }}=$ rotational speed of alternator in rpm. Efficiency is obtained from:

$$
\eta=\frac{P_{\text {elect }} .}{P_{\text {mec }} h} \times 100 \%
$$
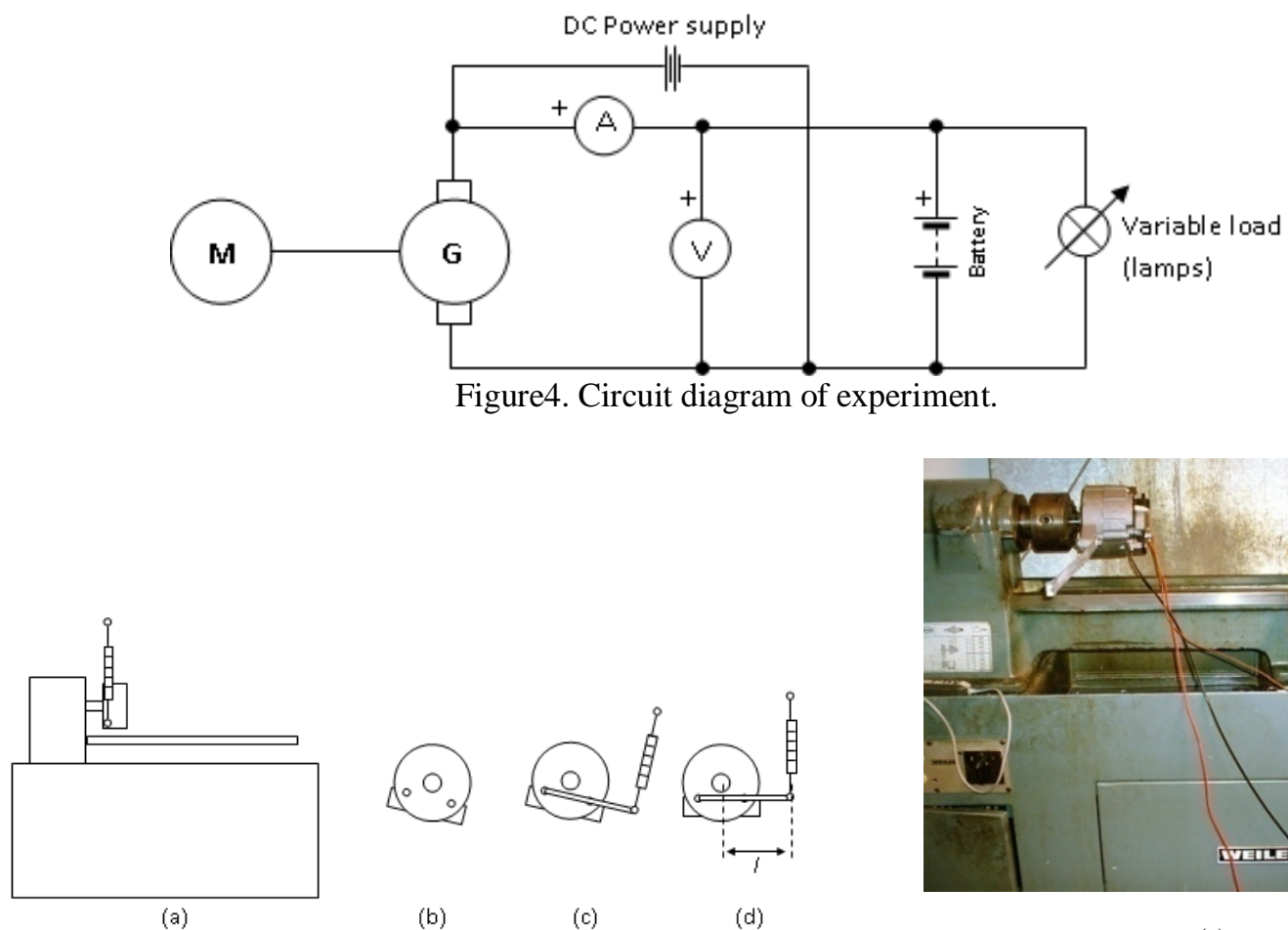

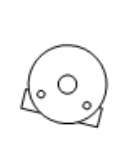

(b)

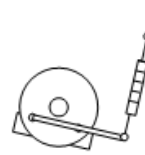

(c)

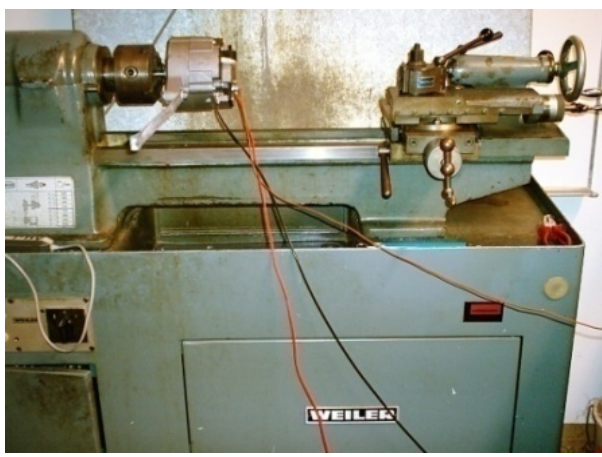

(e)

Figure 5. Torque measurement set-up, (a) The position of alternator onthe lathe machine, (b) Unbalance position at no load condition, (c) Doing measurement using cantilever and newton meter, (d) Measuring position, (e) The alternator and lathe machine used in the experiment. 
Table 1.

Alternator characteristic at 1,070 rpm and excitation current 1.2A.

\begin{tabular}{|c|c|c|c|c|c|c|c|c|}
\hline $\begin{array}{c}\text { Speed, } \\
n_{\text {alt }}(\mathbf{r p m})\end{array}$ & $\begin{array}{c}\text { Excitation } \\
\text { Current (A) }\end{array}$ & $\begin{array}{c}\text { Voltage } \\
\text { (V) }\end{array}$ & $\begin{array}{c}\text { Current } \\
\text { (A) }\end{array}$ & $\begin{array}{c}F \\
(N)\end{array}$ & $\begin{array}{c}\mathrm{T} \\
(\mathrm{Nm})\end{array}$ & $\begin{array}{c}P_{\text {mech }} \\
(\mathrm{W})\end{array}$ & $\begin{array}{c}P_{\text {elect. }} \\
(\mathbf{W})\end{array}$ & $\begin{array}{c}\eta \\
(\%)\end{array}$ \\
\hline \multirow[t]{8}{*}{1070} & 1.0 & 12.44 & 2.04 & 1.5 & 0.525 & 58.83 & 25.38 & 43.14 \\
\hline & & 12.36 & 2.27 & 1.8 & 0.630 & 70.59 & 28.06 & 39.75 \\
\hline & & 12.23 & 2.56 & 1.9 & 0.665 & 74.51 & 31.31 & 42.02 \\
\hline & & 12.07 & 2.86 & 2.0 & 0.700 & 78.44 & 34.52 & 44.01 \\
\hline & 1.2 & 12.36 & 5.70 & 3.4 & 1.190 & 133.34 & 70.45 & 52.84 \\
\hline & & 12.33 & 5.80 & 3.5 & 1.225 & 137.26 & 71.51 & 52.10 \\
\hline & & 12.23 & 6.00 & 3.5 & 1.225 & 137.26 & 73.38 & 53.46 \\
\hline & & 12.04 & 6.24 & 3.6 & 1.260 & 141.18 & 75.13 & 53.21 \\
\hline
\end{tabular}

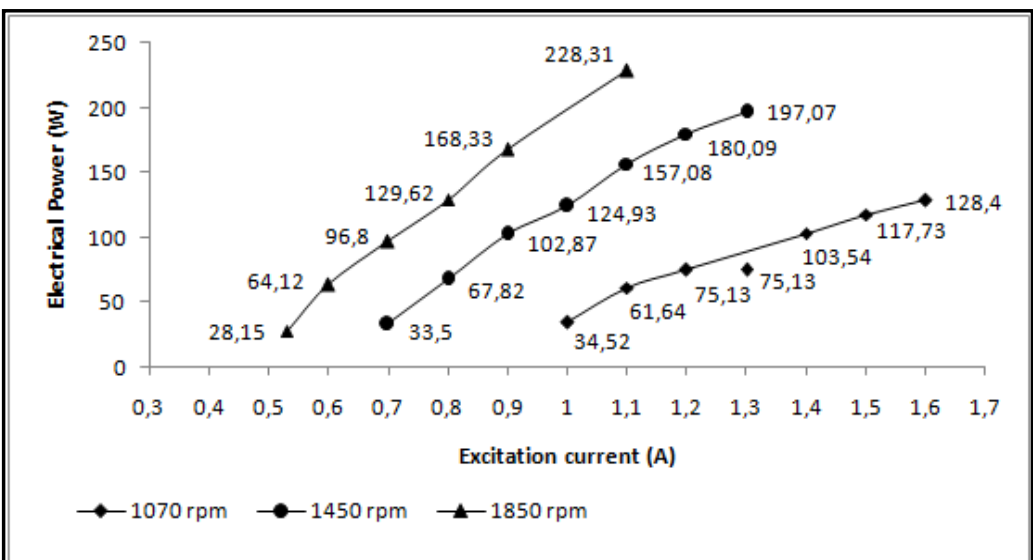

Figure6. Electrical power vs. excitation current at maximum efficiency.

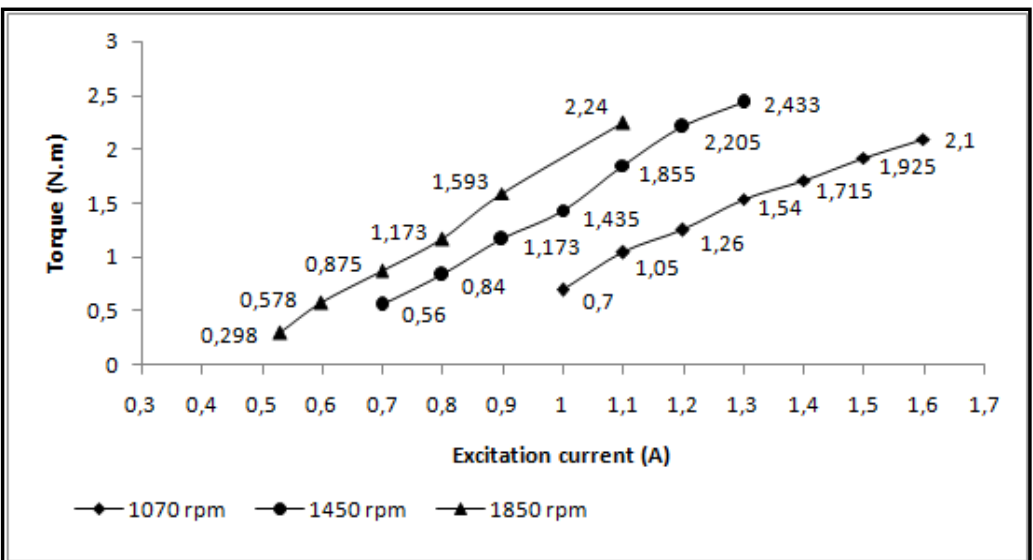

Figure7. Torque vs. excitation current at maximum efficiency.

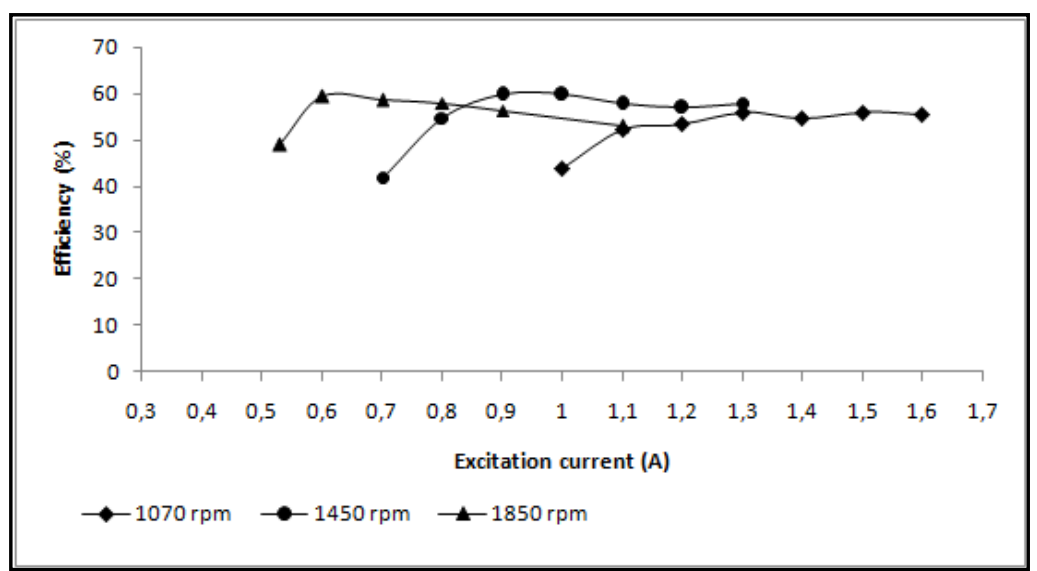

Figure8. Maximum efficiency at diverse rotational speed and excitation current. 
At every period of experiment there is always an achieved maximum efficiency, like $44.01 \%$ and $53.46 \%$ in Table 1 . The theoretical efficiency of a conventional car alternator is around $40-$ $60 \%$ [2][8] and until $70 \%$ for nowadays alternator [13]. Moreover, the alternator characteristics represented by its all maximum efficiencies at every excitation current and speed setting are presented in Fig. $6-8$.

Fig. 6 \& 7 show that with the same excitation current, the electrical power at $1850 \mathrm{rpm}$ is always higher than the others. To obtain higher electrical and mechanical power with the same speed, the excitation current should be enhanced. However, referring to Eq. (3), the increase of mechanical power means the torque also becomes higher. For wind turbine application, this causes the increase of required wind speed to produce the same power output and of cut-in wind speed. While if the excitation current is small, high speed is needed to reach big power output. It can be achieved by installing a high transmission ratio which could lead to higher transmission losses so the wind turbine becomes inefficient. By implementing a controlled excitation current, some of the energy of the battery will be drawn by the controller, the delivered energy to consumers therefore is diminished. In this research, the excitation current is not controlled but is set at a certain point.

Fig. 8 shows the efficiency graph of the generated power displayed in Fig. 6 \& 7. Unlike the power curve which tends to ascend, the efficiency curve shows little increase until a certain point but then almost flat and tends to decrease due to core saturation [14].

\section{Alternator Characteristic - Tip Speed Ratio Correlation}

It is already known that the ratio of mechanical transmission will affect directly to the wind turbine system performance. The higher the ratio, the higher the starting torque and the maximum power reached. The other way will be if the ratio is lower. Since in wind turbine system the mechanical transmission connecting rotor blades and electric generator in which each has its optimum characteristic that should be maintained, therefore, the ratio of mechanical transmission should be able to meet as lowest cut-in wind speed or starting torque as possible and as highest maximum power as possible

In this research, the mechanical transmission employed is pulley belt for cost and ease of manufacture considerations. The calculation of pulley ratio is approached with assuming:

1. the tip speed ratio $\lambda$ is in the range of $5-11$ (Fig. 3)

2. the wind speed $V_{\text {wind }}$ is between $3-6 \mathrm{~m} / \mathrm{s}$ (the most average wind speed in Indonesia's regions [15])

The correlation between wind speed and tip speed ratio is expressed as [12]

$$
\lambda=\frac{2 \cdot \pi \cdot R \cdot n_{w t}}{60 \cdot V_{\text {wind }}}
$$

with $\mathrm{R}=$ radius of rotor blade $=0.85 \mathrm{~m}$.

Eq. (5) shows the reverse correlation between $\lambda$ and $V_{\text {wind }}$ and the proportional correlation of the shaft speed $n$ and $\lambda$.

However, from Fig. 2 and Eq. (5), it cannot be determined surely the value of lambda and $c_{p}$ since they always change with the change of the wind. Therefore it is made a hypothesis: "If the wind speed increases the rotation of the wind turbine will also increase and the extracted power will increase as well. The increase of power causes the increase of the load (current flowing to the battery), which will generate an adverse torque to the rotor shaft and consequently decreases the rotation of the wind turbine so that it will always go back to the maximum value of $c_{p}$ ". Hence, the correlation among them can be illustrated as shown in Fig. 9.

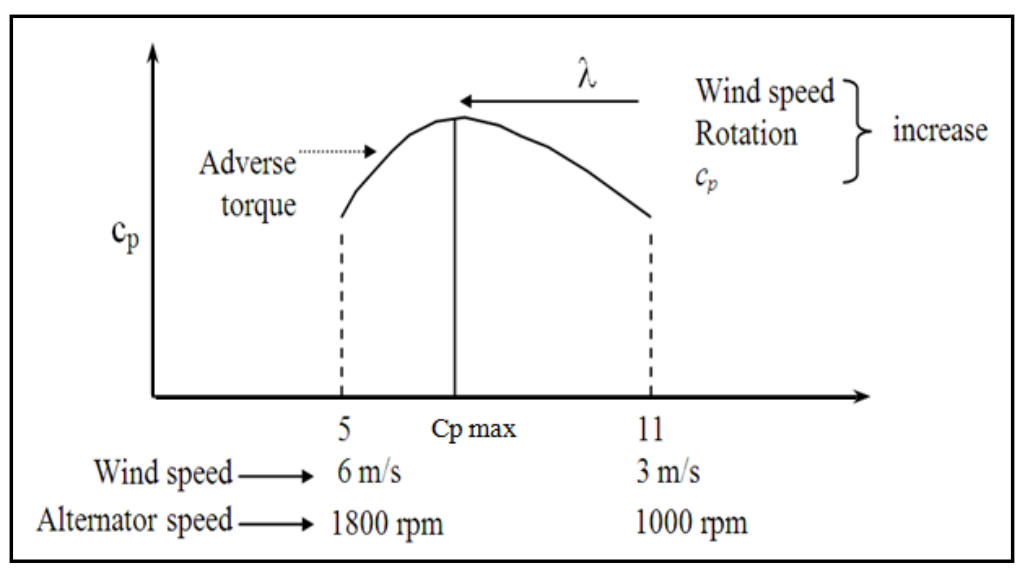

Figure 9. Correlation among wind speed, alternator speed, lambda, and power coefficient. 
The minimum blade shaft speed $\mathrm{n}_{\mathrm{wt}}$ is obtained by substituting the minimum value of $\lambda$ and $V_{\text {wind }}$ into Eq. (5):

$$
n_{w t(\min )}=\frac{60 \cdot 11 \cdot 3}{2 \cdot \pi \cdot 0.85}=370.73 \mathrm{rpm}
$$

The minimum gearbox ratio is found as:

$$
\begin{aligned}
\text { gearbox ratio }(\min ) & =\frac{n_{\text {alt }(\min )}}{n_{w t}(\min )} \\
& =\frac{1000}{370.73}=2.697
\end{aligned}
$$

Similarly, the calculation is conducted for the maximum gearbox ratio, yielding 5.3 with the blade shaft rotation of $337 \mathrm{rpm}$. From both options, the smaller gearbox ratio (rounded up to 3 ) is chosen by considering the transmission losses.

Refering to the alternator experiment result and the pulley ratio calculation, the excitation current is set to 1.6 A and little higher at 1.7 $\mathrm{A}$ in order to gain big power output. The starting torque is not taken into account as the system will be simulated using wind tunnel.

\section{Wind Turbine Performance Test}

After getting the alternator characteristic and choosing the suitable transmission ratio, the alternator is then integrated to the wind turbine to be tested as a unity system. The experiment method for wind turbine system is similar to that of the alternator except the lathe machine is substituted by the wind tunnel. The wind turbine experiment set-up is illustrated in Fig. 10. Relating to Fig. 8, a DC power supply is employed to inject excitation current to the alternator with the magnitude of $1.6 \mathrm{~A}$ and $1.7 \mathrm{~A}$ for each experiment. The load is battery with initial voltage about $12 \mathrm{~V}$. The experiment is started by blowing wind from wind tunnel, turning the rotor blades. The data are recorded when the blade rotation is considered stable, covering the rotor shaft speed, battery current and voltage. The wind speed is gradually increased by $0.5 \mathrm{~m} / \mathrm{s}$ until the battery voltage has reached around $13 \mathrm{~V}$. At every speed setting, the same data is recorded.

The considered maximum wind speed is when the system becomes unstable. At this point the experiment is ended to avoid damage.

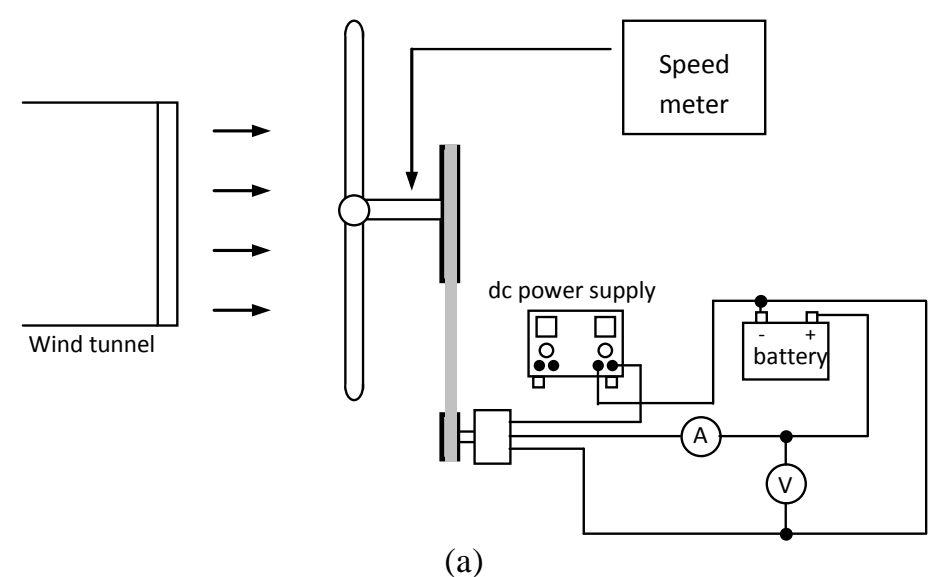

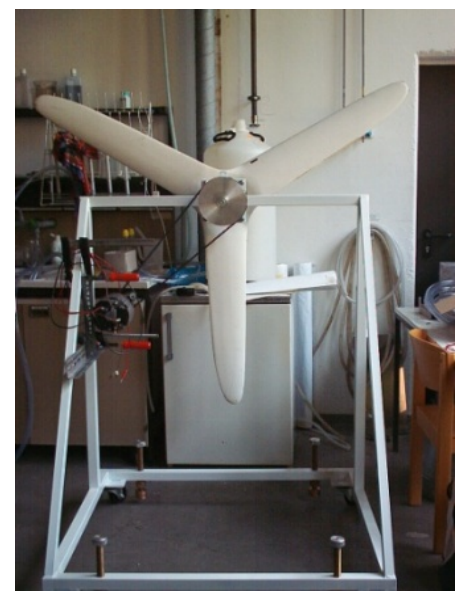

(b)

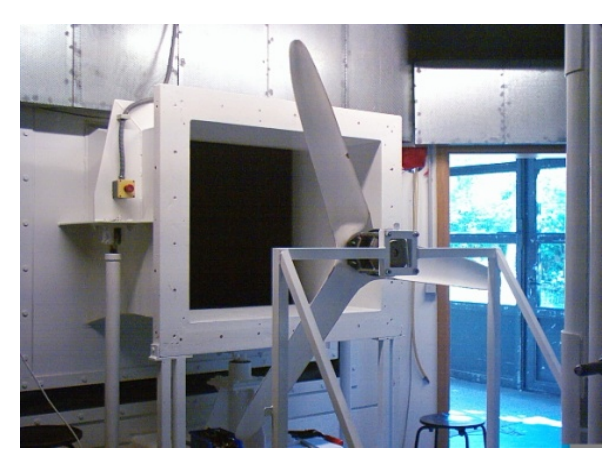

(c)

Figure 10. Small wind system experiment set-up (a) Experiment configuration, (b) Blades and alternator set-up, (c) Wind turbine and wind tunnel set-up. 


\section{E. The Experiment Drawback}

The experiment drawback is that the dimension of wind tunnel is smaller than that of the rotor blades. This causes not all of blade area swapped by the wind blown from the tunnel. Both dimensions are illustrated in Fig. 11.

The power of the wind is calculated using [16]:

$$
P_{w}=\frac{1}{2} \cdot \rho \cdot C_{p} \cdot \pi \cdot R^{2} \cdot V_{\text {wind }}^{3}
$$

where $\rho=$ air density $(1.25 \mathrm{~kg} / \mathrm{m} 3), R=$ blade radius $=850 \mathrm{~mm}, V_{\text {wind }}=$ wind speed, $C_{\mathrm{p}}=$ power coefficient.

Due to the mismatch dimension, the swapped blade area $\left(\pi R^{2}\right.$ in Eq. (6)) is amended by the wind tunnel area. The ratio of the ideal wind power generated by wind turbine $P_{\mathrm{wT}}$ to the wind power after being corrected by wind tunnel area $P_{\text {w(experiment) }}$ is:

$$
\begin{aligned}
\frac{P_{W T}}{P_{W(\text { experiment })}} & =\frac{1 / 2 \rho V_{\text {wind }}^{3} c_{p}\left(\pi 0.85^{2}\right)}{1 / 2 \rho V_{\text {experiment }}^{3} c_{p}(0.8 \cdot 1)} \\
& =\frac{2.27}{0.8}=2.8
\end{aligned}
$$

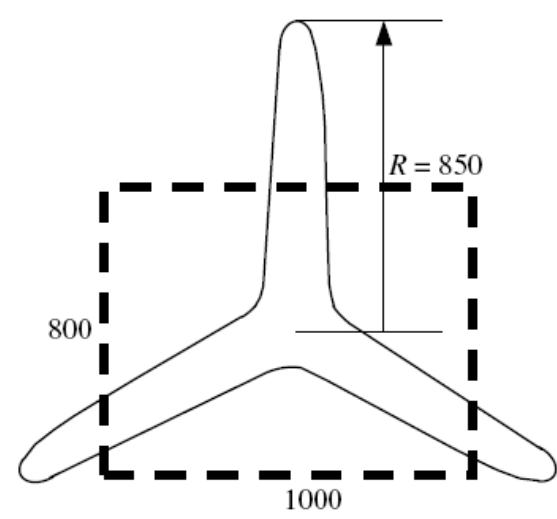

Figure 11. The mismatch dimension between the wind turbine and wind tunnel.
The ratio of 2.837 means that with the same wind speed, the power generated by actual wind speed is higher than that of the wind tunnel (experiment). The power correction does not take into account the blade aerodynamic factor. To find out the magnitude of the equity of terrain wind speed, the approach calculation is as follows:

$$
\begin{aligned}
& P_{W T}=P_{W(\text { experiment })} \\
& \frac{1}{2} \cdot \rho \cdot 2.27 \cdot V_{\text {wind }}^{3}=\frac{1}{2} \cdot \rho \cdot 0.8 \cdot V_{\text {experiment }}^{3} \\
& V_{\text {wind }}=0.706 \cdot V_{\text {experiment }}
\end{aligned}
$$

Substituting $V_{\text {wind }}$ into Eq.(6)

$$
P_{w}=\frac{1}{2} \cdot \rho \cdot C_{p} \cdot \pi \cdot R^{2} \cdot 0.706 \cdot V_{\text {experiment }}^{3}
$$

\section{Result AND Discussion}

The graphs of the power curve and wind turbine efficiency are illustrated in Fig. 12. The displayed wind speed is terrain wind speed calculated using Eq. (7).

Fig. 12 shows that there is no significant difference between the excitation current 1.6A and 1.7A in yielding the power; even the two curves are close together. The cut-in wind speed arises at about $6.35 \mathrm{~m} / \mathrm{s}$, much higher than that of the commercial wind turbine which is in the range of $2.5-3 \mathrm{~m} / \mathrm{s}$. If the cut-in wind speed is required to be smaller, then the excitation current should be decreased. However, it will reduce the achieved maximum power, as shown in Fig. 6. If the efficiency of alternator and mechanical transmission are assumed to be $55 \%$ and $90 \%$ [17] respectively then the efficiency of the wind system is $49.5 \%$.

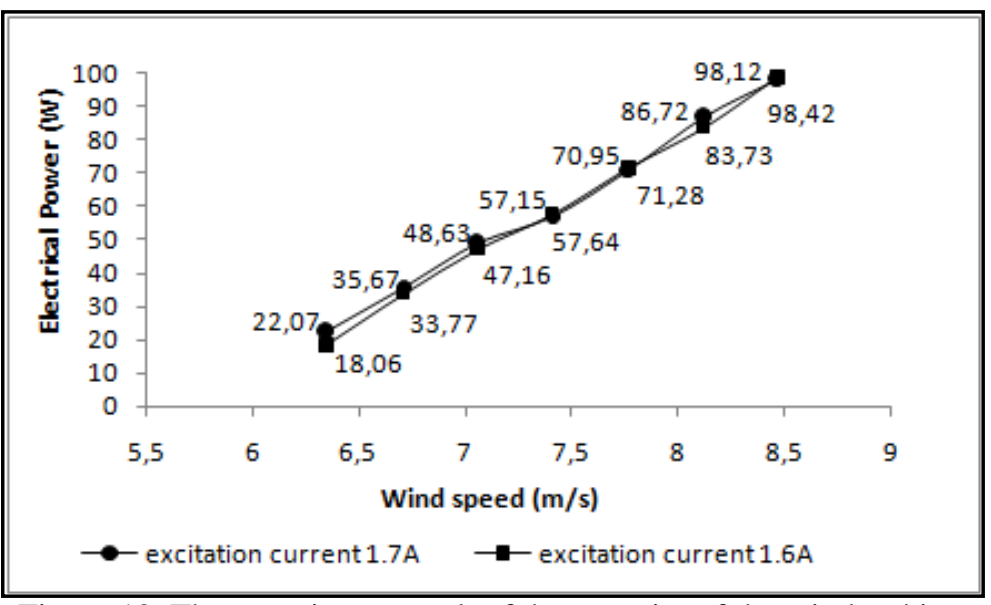

Figure 12. The experiment result of the capacity of the wind turbine. 
Table 2.

The Rotation of alternator and blade shaft of alternator.

\begin{tabular}{|c|c|c|c|c|}
\hline \multirow{3}{*}{$\begin{array}{c}V \\
(\mathrm{~m} / \mathrm{s})\end{array}$} & \multicolumn{4}{|c|}{ Excitation current } \\
\hline & \multicolumn{2}{|c|}{ 1.7A } & \multicolumn{2}{|c|}{$1.6 \mathrm{~A}$} \\
\hline & $n_{w t}(\mathbf{r p m})$ & $n_{\text {alt }}(\mathrm{rpm})$ & $n_{w t}(\mathbf{r p m})$ & $n_{\text {alt }}(\mathrm{rpm})$ \\
\hline 6,35 & 320 & 960 & 320 & 960 \\
\hline 6,71 & 330 & 990 & 330 & 990 \\
\hline 7,06 & 340 & 1020 & 340 & 1020 \\
\hline 7,41 & 350 & 1050 & 360 & 1080 \\
\hline 7,77 & 360 & 1080 & 360 & 1080 \\
\hline 8,12 & 360 & 1080 & 375 & 1125 \\
\hline 8,47 & 360 & 1080 & 380 & 1140 \\
\hline
\end{tabular}

By using pulley belt ratio of $1: 3$, the rotation of the blades and alternator are shown in Table 2. As predicted, the car alternator starts generating electrical power at $960 \mathrm{rpm}$ or close to $1000 \mathrm{rpm}$. Some data in Table 2 show that the increase of wind speed is not always followed by the increase of the alternator rotation. Nevertheless, the output power of alternator (Fig. 12) goes up. It means that the reverse torque generated by the alternator also raises, preventing alternator to rotate faster.

\section{CONCLUSION AND RECOMMENDATION}

The experiment results show that the car alternator with fixed excitation current can be implemented for wind turbine (up to $1 \mathrm{~kW}$ ) but its efficiency is very low (around 50\%) and it starts producing electric power at high speed (approximately $1000 \mathrm{rpm}$ ). The output power can be improved by enhancing the transmission ratio or excitation current but it will increase the starting torque and cut-in wind speed at once in consequence. Therefore, the use of alternator for wind turbine application is not recommended.

\section{REFERENCES}

[1] Anonim, Terbebas dari pemadaman bergilir, Rasio elektrifikasi masih 66\%, [online], Available: http://www.kabarbisnis.com/energi/kelistri kan/2813532Terbebas_dari_pemadaman_b ergilir_Rasio_elektrifikasi_masih_66_.ht ml. accessed on 28 January 2011

[2] S. Whid, L.R. Peiris, P. Laan, Sandagiri. CA, Siriwardena. KAP, Introduction of Car Alternators for Small Scale Wind Power Generation, [online], Available: http://www.elect.mrt.ac.lk/ug_papers/p09_ oct04.pdf, accessed on 25 March 2011

[3] H. Fernández, A. Martínez, V. Guzmán and M. Giménez. (2004, April). Wind
Turbine Generation System Implemented with a Car Alternator for Use in Isolated Locations. Presented at ICREPQ. [Online]. Available:

http://www.icrepq.com/PONENCIAS/4.28 8.FERNANDEZ.pdf

[4] J.-L. Menet. (2004). Adouble-step Savonius Rotor for Local Production of Electricity: A Design Study, Renewable Energy29, pp. 1843-1862.

[5] D.J. Perreault, V. Caliskan, A New Design for Automotive Alternators, [online], Available: http://leesweb.mit.edu/lees/dperreault/ConferencePa pers/cpConvergence00p583.pdf, accessed on 26 March 2011.

[6] C. Ofria, A Short Course on Charging Systems [online], Available: http://www.alternatorparts.com/understand ing_alternators.htm, accessed on February 2011

[7] P. Irasari, Small Wind System, Master Thesis, Carl Von Oszietsky University. Oldenburg. 2003. Germany.

[8] D.M. Whaley, W.L. Soong and N. Ertugrul. (2004, September). Extracting More Power from the Lundell Car Alternator. Presented at AUPEC [online]. Available: http://itee.uq.edu.au/ aupec/aupec04/paper s/PaperID82.pdf

[9] A. Gálvez, M. Lejárraga, J. S. Artal, A. Usón and F.J. Arcega. (2003, April). Recycling of Small Electrical Machines and Its Applications for Low Cost Wind Turbines, Presented at ICREPQ [online]. Available:

http://www.icrepq.com/pdfs/Galvez393.pd $\mathrm{f}$

[10] M.B. Robert, W. Grove, N.H., "Dynamometer Torque Arm and Dynamometer Assemby,” US Patent5,370,003,Dec. 6, 1994 
[11] F. Sahin, Design and Development of A High-Speed Axial-Flux Permanent-Magnet Machine, Ph.D Thesis, Technische Universiteit Eindhoven, 2001, Netherland.

[12] N.S. Çetin, M.A. Yurdusev, R. Ata and A. Özdemir. (2005). Assessment of Optimum Tip Speed Ratio of Wind Turbines, Mathematical and Computational Appl., Vol. 10, No. 1, pp. 147-154

[13] A.Gimeno, G.Friedrich, K.El-kadribenkara, "Experimental and Numerical Evaluation of Iron Losses in a Claw Pole Car Generator," in Proc.ICEM XIX, 2010, pp. $1-6$.

[14] E.S. Hamdi, Design of Small Electrical Machines, England: John Wiley \& Sons, 1994, pp. $2-11$
[15] A. Hardoko and Soeripno. (2008, November). Prospect of Wind Energy Development in Indonesia. [Japan Indonesia Symposium \& Expo]

[16] T. Burton, D. Sharpe, N. Jenkins and E. Bossanyi, Wind Energy Hand Book, England: John Wiley \& Sons, 2001, pp. 44 $-46$

[17] Energy Loss and Efficiency of Power Transmission Belts. Carlisle Power Transmission Products, Inc. Atlanta, Georgia, Third World Energy Engineering Congress. [Online]. Available: http://www.cptbelts.com/pdf/misc/energy_ loss_and_belt_efficiency.pdf, accessed on 5 April 2011 